УДК 377.112.4

\title{
ОСНОВИ ТЕОРІЇ ЗАПИТАНЬ У СУЧАСНІЙ ПРИРОДНИЧІЙ ОСВІТІ
}

\author{
Віктор Надточій \\ доктор фізико-математичних наук, професор, завідувач кафедри фізики \\ ДВНЗ «Донбаський державний педагогічний університет» \\ м. Слов'янськ, Україна \\ ORCID ID 0000-0002-6289-0438 \\ nadtochiivn@gmail.com

\section{Віталій Масич} \\ доктор педагогічних наук, доцент, \\ завідувач кафедри фізики та кіберфізичних систем \\ Харківський національний педагогічний університет імені Г. С. Сковороди \\ м. Харків, Україна \\ ORCID ID 0000-0002-8943-7756 \\ jugosloven9@yandex.ru
}

\section{Юлія Лимарєва}

кандидат педагогічних наук, доцент кафедри фізики ДВНЗ «Донбаський державний педагогічний університет»

м. Слов'янськ, Україна

ORCID ID 0000-0002-5828-0231

ulialymareva23@gmail.com

Анотація. У статті порушено проблему використання запитань при вивченні фізики в закладах загальної середньої та вищої освіти. Здійснено спробу систематизувати основні теоретичні питання з поставленої проблеми. Представити запитання як педагогічно доцільний та дидактично виправданий засіб сучасного навчання, що лежить в основі педагогіки співпраці та самоосвіти. Висвітлено зміну функції запитання лише 3 контрольної на навчальнопошукову. Доведено, що запитання в сучасній освіті $\epsilon$ «рушійною силою», розглянуто підстави для виникнення та етапи формування запитань, а також завдання для викладача щодо сприяння їх виникненню. Вирішення проблеми не є одномоментним як і весь процес навчання особистості, але саме вміння ставити запитання є виміром сучасного свідомого сприйняття особистістю навчального матеріалу та розуміння його практичної значущості.

Ключові слова: запитання; підгрунтя; зацікавленість; інтерес; усвідомлення; логічний зв'язок; навчання; самоосвіта.

Постановка проблеми в загальному вигляді. Тенденції активної зміни методів навчання 3 пасивних на активні вимагають щільної взаємодії всіх учасників навчального процесу. Така взаємодія можлива лише за умови побудови навчання в циклі «запитання - відповідь - запитання», при цьому «запитання» має виступати ключовим у підтримці системи в робочому стані. Тому вивчення проблеми запитань є надзвичайно важливою передусім для

() ДВНЗ «Донбаський державний педагогічний університет» 
організаторів навчального процесу. Окрім того, що вони ставлять запитання різних рівнів складності та з різною метою, вони відтепер для організації плідної взаємодії мають навчити студентів (або учнів) ставити запитання. Тому проблема запитань має бути розглянута як найширше та в різних іiі аспектах. Особливо гострою вона постає у вивченні природничих дисциплін з огляду на загальноприродниче та профільне їх вивчення.

Аналіз останніх досліджень і публікацій. Окремі аспекти зазначеної проблеми відображають у працях сучасні вітчизняні та іноземні науковці В. Андреєв, Т. Вокер, Н.Волкова, І. Гавриш, Р. Гуревич, О. Дубасенюк, М. Сметанський та інші.

Винахідливість особистості, активне висунення чисельних гіпотез та зацікавленість протиріччями провокує виникнення запитань, а тому для формування ініціативності учнів в аспекті зовнішнього впливу на творчій розвиток особистості, запитання як метод самооцінювання та самоконтролю $\epsilon$ індикатором рівня творчого потенціалу (Андреєв, 2000).

Навчання в грі, розмові, дискусії та рівному діалозі учасників; парна або групова робота; бажання учня - це закон, а вчитель - друг, який лише допомагає зрозуміти істину - основи навчання у «вільній школі». Тому необхідністю в організації плідного навчального процесу $є$ переконання учнів у тому, що просити поради - це цілком природно, а наявність розбіжностей у думках провокує створення діалогового навчального середовища та відповідно отримання відповідей на багато запитань (Вокер, 2018).

Запитання у творчій та навчально-пізнавальній діяльності особистості відіграють важливу роль та займають почесне місце. Діяльнісний підхід при цьому виступає як основа виникнення запитань, учнівська допитливість природна потреба людини, в основі якої є мотив задоволення власних потреб (Сметанський, 2000).

Педагогічне бачення навчальної проблеми як основи для запитань, розгляд діалогового навчання в контексті професійно-педагогічної діяльності, створення конструктивного діалогу поколінь крізь розвиток науки переконують у тому, що вчитель може навчити лише тому, що знає та чим володіє сам (Волкова, 2006; Гавриш, 2006).

Формулювання цілей статті. На основі зазначеного вище за мету статті ставимо висвітлення ключових моментів у навчанні особистості формуванню та формулюванню запитань упродовж навчальної діяльності, а саме: вивчення природничих дисциплін у закладах освіти різних рівнів акредитації.

Результати дослідження. Поставлена проблема, за умови врахування сучасності погляду на неї, вимагає якомога швидшого вирішення та з'ясування

Професіоналізм педагога: теоретичні й методичні аспекти. - Вип. 11. - Слов’янськ, 2019. 
всіх супровідних із нею питань.

«Питання» та «запитання»... Що спільного та в чому різниця? В освіті відповідь на нього $є$ найбільш важливою. Отже, ЗАПИТАННЯ передбачає з'ясування протиріччя, невідповідності, отримання додаткових знань та отримання цілком конкретної відповіді. ПИТАННЯ ж постає як проблема, що вимагає обговорення та прийняття виваженого рішення щодо їі вирішення на основі бесіди або дискусії. «ПИТАННЯ» = «ПРОБЛЕМА», яка може бути поставлена щодо (чогось) або стосовно (чогось). Проблема може бути поставлена (подана, задана) у формі запитання. Отже, запитання часто виступає формою постановки проблеми або способом її конкретизації.

Запитання сьогодні являє собою рушійну силу розвитку науки та суспільства. Прогрес є ні чим іншим як результатом послідовної постановки запитань та своєчасного отримання відповідей на них. Усвідомлення потреби в набутті певних знань невідривно пов'язане із запитанням «навіщо?» («Навіщо ці знання мені потрібні?»). Втрата відповіді на чергове «навіщо?» призводить до зупинки, стояння на одному місці, що насамперед $\epsilon$ деградацією. Поняття деградації $є$ відносним. У сучасних умовах, якщо не розвивається окрема особистість, то це не означає, що не розвиваються інші та суспільство загалом. Отже, відносно суспільства поодинока особистість деградує (рухається в протилежному напрямку).

Кожна відповідь на «навіщо?» підкріплюється зацікавленістю або потребою, тобто спостерігаємо наявність мотивації. До того ж у другому випадку передбачається більш стійка мотивація порівняно з першим. Вона передусім поділяється на мотивацію «від (чогось)» та мотивацію «до (чогось)». Перша 3 них характерна для розвитку суспільства 3 його проблемами, від яких $\epsilon$ необхідність позбавитися, та людини як окремої його одиниці; друга ж переважно супроводжує науковий розвиток та значення особистості в ньому. У більшості мотивація «від» $є$ значно потужнішою за мотивацію «до». До тих пір, поки особистість не набуде впевненості в собі стосовно того чи того питання, «від» буде домінувати над «до». Отже, запитання в будь-якому разі виступає потужним мотиватором активної пошукової діяльності та індикатором рівня іiі активності.

Першочерговість запитання перед визначенням відповіді має глибші корені, ніж ми собі зазвичай уявляємо. Людина впродовж свого повсякденного життя та професійної діяльності значно більше формує запитань, ніж створює та отримує відповідей. Отже, робота із запитаннями цілком природна. Усе життя особистості постає у вигляді запитань та відповідей. Причому запитань значно більше, ніж відповідей. Так, наприклад, в основі будь-якої проблеми лежить 
запитання або кілька запитань, отримання відповіді провокує виникнення додаткових запитань із метою отримання додаткової інформації та уточнення відомостей. Якщо відповідей кілька (наприклад, поради кількох людей), то виникає ще більше уточнювальних запитань і запитань порівнювального плану. Усунення суперечностей теж відбувається за наявності запитань.

Для виникнення запитань завжди має бути підстава. Вона включає в себе основу (причину), яка спонукала до виникнення та забезпечила формулювання запитання, а також мотив для його з'ясування (для отримання відповіді).

Підстави виникнення запитань засновані переважно на зацікавленості особистості або іiі бажанні усунення суперечностей. Вони є первинними в організації співпраці основних суб'єктів навчально-виховного процесу та одночасно виступають мотивом до прояву активності особистості в навчанні й ознакою свідомого сприйняття студентом інформації запропонованої викладачем та наявності мотивів виконання елементарних дій для задоволення зацікавленості чи усунення суперечностей через отримання відповіді на запитання, що виникло.

Підстави (мотиви) з'ясування запитань містять (об'єднують) у собі підстави виникнення запитань та підстави подальшого успішного використання навчального матеріалу в практичній діяльності особистості. Такі мотиви доцільно поділити на такі, що ситуативно задовольняють потреби особистості (нестабільні) та ті, що несуть у собі перспективу самоосвіти (стабільні) й сприяють підтримці активізації діяльності особистості до отримання власної освіти й організації на належному рівні самоосвіти. Можливість обгрунтування особистістю підстав для з'ясування запитань, що в неї виникли впродовж навчального процесу свідчить про високий рівень іiі свідомого підходу отримання освіти.

На основі вищезазначеного слід акцентувати увагу, що вказані підстави $€$ взаємопов'язаними: за відсутності перших неможливе виникнення мотивів другої групи. Якщо перші забезпечують «старт», то другі створюють «шлях», яким необхідно крокувати для успішного життя в суспільстві, що змінюється із шаленою швидкістю, та до якого треба постійно пристосовуватися особистості, аби не залишитися осторонь життя взагалі.

Підставою для виникнення запитань $€$ :

- незрозумілість;

- невідповідність (протиріччя);

- новизна (зацікавленість);

- необхідність (потреба у вирішенні проблеми). 
Запитання не з'являється «не звідки». Процес формування запитання проходить кілька етапів:

1. Передача інформації викладачем (наявність вхідної інформації).

2. Сприйняття студентом вхідної інформації.

3. Внутрішня обробка інформації особистістю.

4. Виявлення суперечностей між відомим та новим.

5. Встановлення (конкретизація) підгрунтя для запитання.

6. Усвідомлення особистістю необхідності отримання відповіді на запитання, важливість отримання додаткової інформації.

7. Формування та формулювання запитання.

Виходячи із зазначеного вище, доцільно акцентувати увагу на педагогічному сприянні виникненню запитань.

Найпростіші запитання - де? коли? навіщо? чому? хто? що? як? - можуть виникати необмежену кількість разів на різних етапах навчання та завдяки різним технологічним прийомам. Виникнення в особистості запитань - процес цілком природний та заснований на зовнішньому впливі на органи чуття й створенні суто ситуації зацікавленості.

Отже, першим завданням, що стає перед педагогом - зацікавити. Далі педагогічний процес вимагає потужного потенціалу для підтримання зацікавленості. Така підтримка часто забезпечується використанням низки запитань на фоні монологічного діалогу педагога. За такого підходу активізується розумова діяльність особистості. Зазначений метод указує на варіативність можливих підходів до усвідомлення запитань, а відповідно й навчального матеріалу. Завдяки низці запитань, запропонованих педагогом, кожний із студентів самостійно відзначає, на якому саме з них зосередитися, яке саме 3 них його зацікавило найбільше, та самостійно визначити «рейтинг» кожного $з$ них для власної освіти. Іноді вже на цьому етапі виникають особисті запитання. Частіше за все вони з'являються за аналогією. Це є проявом найвищої ефективності роботи зазначеного етапу постановки та використання запитань у навчальному процесі.

У викладанні природничих дисциплін підставою для формування запитань може стати:

- викладення суперечливих фактів;

- встановлення логічного ланцюжка передбачає створення системи запитань;

- навчальні демонстрації;

- спостереження явищ природи та практичний досвід особистості;

- побутові та літературні помилки тощо. 
За рівнем свідомості постановки запитань їх можна поділити на:

1. Ситуативні. Базуються переважно на зацікавленні. До них можна віднести прості та короткі запитання (чому? що? навіщо? як? коли? тощо).

2. Обгрунтовані. 3'являються, коли особистість може повідомити, що саме спонукало $\dddot{11 ~ д о ~ з а п и т а н н я ~(з а з н а ч а є ~ п і д г р у н т я ~ з а п и т а н н я) . ~}$

3. Усвідомлені. Виникають, коли особистість:

- обгрунтовує підстави запитання;

- викладає можливі власні варіанти відповіді, усвідомлює необхідність отримання відповіді;

- бачить перспективи доцільності ії використання.

Важливість розуміння викладачем, до якої категорії запитань належить те чи те запитання, пояснюється гарантованою економією часу: винайдення подальшої стратегії спілкування 3 конкретною особистістю. Згідно $з$ рівнем свідомості постановки запитання слід визначити глибину та доцільність відповіді або пропонувати технологію пошуку відповіді самим студентом чи у співпраці з викладачем. Сдине, що має за цих умов залишатися незмінним - це відчуття студентом педагогічної підтримки на будь-якому етапі навчання та в пошуках відповідей на запитання будь-якої складності.

Довгий час запитання розглядалося як прийом контролю, і в такий спосіб створювали ситуацію психологічного дискомфорту для студентів. Окрім того, якщо особистість не в змозі одразу відповісти на поставлене запитання, то робився висновок про недостатню компетенцію стосовно запропонованої проблеми. Сдиним виходом із ситуації ставали або додаткові, або «навідні» запитання. Як свідчить проведене дослідження, перші 3 них ще більше заплутували особистість i, як результат, вона не давала відповіді, а другі призводили до того, що педагог сам давав відповіді.

Додаткові запитання можуть бути поставлені:

- для уточнення суті вже поставленого запитання, тобто його переформулювання або конкретизації;

- для з'ясування глибини усвідомлення відповіді, що надається на основне запитання.

«Навідні» запитання з'являються там, де є:

- необхідність у конкретизації основного запитання;

- потреба в спрощенні змісту або скороченні об'єму передбачуваної відповіді на основне запитання;

- демонстрація логічної послідовності в проблемі, що розглядається.

«Уточнювальні» запитання використовуються:

- для конкретизації змісту чи об’єму відповіді; 
- встановлення найбільш важливих аспектів, що мають бути висвітлені у відповіді;

- формулювання мети очікуваної відповіді;

- визначення меж розгляду питання тощо.

Донедавна «уточнювальні» запитання були прерогативою викладача, але зміна методів i прийомів навчання подала в новому вигляді роботу із запитаннями в навчальному процесі та на існування «уточнювальних» запитань. У сучасній освіті такі запитання впродовж спілкування можуть ставити й студенти. Які ж переваги в цьому?

1. Для педагога:

- на основі поставлених запитань може отримати загальні уявлення про рівень володіння матеріалом;

- отримує інформацію про рівень усвідомлення проблеми, що розглядається;

- намагається отримати відповідь для себе особисто щодо професійності (правильності, коректності однозначності) постановки запитань (це його самоосвіта);

- усвідомлення, розширення варіативності постановки проблем.

2. Для студента (учня):

- уточнити, конкретизувати запитання для надання відповіді;

- отримання додаткового часу на обмірковування відповіді;

- отримання можливих підказок у відповіді викладача на студентське запитання;

- можливість показати рівень власної компетенції;

- спроба надати відповідь на те запитання, відповіді на яке особистість не знає, але орієнтується наближено в цій темі або сумісних із нею;

- може показати знання практичного використання матеріалу без конкретизації теорії;

- може акцентувати увагу викладача на тому матеріалі, що йому відомий, і в такий спосіб спростувати переконання викладача про незнання навчального матеріалу;

- окреслити коло своїх інтересів;

- отримати відповіді на запитання, які істинно цікавлять особистість;

- сформувати істинне враження від наукових відомостей;

- скласти алгоритм подальшої самоосвітньої діяльності;

- переконатися в правильності або хибності вражень від навчання та самоосвітньої діяльності;

- 'ясувати та усвідомити технологію власної самоосвітньої діяльності.

() ДВНЗ «Донбаський державний педагогічний університет» 


\section{Висновки 3 дослідження і перспективи подальших розвідок у цьому} напрямі. Взаємодія основних суб'єктів навчального процесу на основі запитань $€$ потужним «вічним двигуном» у набутті знань у закладах освіти та мотиватором для подальшої самоосвітньої діяльності впродовж життя. Сучасні викладачі мають докласти максимальних зусиль аби сприяти формуванню в студентів та учнів уміння формулювати запитання, поєднувати їх у логічні ланцюжки, установлювати та обгрунтовувати причинно-наслідкові зв'язки їхнього виникнення.

У такий спосіб відбувається свідоме навчання та усвідомлення методів і прийомів пошуку, накопичення, систематизації, обробки та застосування інформації. Це яскрава демонстрація пошукового підходу до оволодіння знаннями з метою вмотивованого та свідомого їхнього застосування.

Зміна підходів до організації навчального процесу в закладах освіти вимагає детальнішої конкретизації та розгляду запитань в аспекті дидактичних і методичних особливостей викладання окремих навчальних дисциплін. Особливо це стосується природничих наук. Тому, беручи до уваги зазначене вище, перспективи подальших розвідок полягають у створенні методичних розробок за різними розділами фізики з організації вивчення дисципліни на основі запитань та рекомендацій до їхнього використання в навчальному процесі.

\section{СПИСОК ВИКОРИСТАНИХ ДЖЕРЕЛ}

1. Андреев, В. И. (2000). Педагогика: учебный курс для творческого саморазвития. Казань, Россия: Центр инновационных технологий.

2. Вокер, Т. (2018). Як навчають у Фінляндії. Найкраща шкільна освіта. Н. Лавська (Перекл.). Київ, Україна: Видавнича група КМ-Б.

3. Волкова, Н.П. (2006). Професійно-педагогічна комунікаиія. Київ, Україна: Видавництво ВЦ «Академія».

4. Гавриш, I. В. (2006). Теоретико-методологічні основи формування готовності майбутніх учителів до інноваційної професійної діяльності. (Автореф. дис. д-ра пед. наук). Луганськ, Україна.

5. Гуревич, Р. С. (2014). Компетентнісний підхід у професійно-педагогічній освіті. Компетентнісний підхід в освіті: теоретичні засади і практика реалізації: Методол. семінар Наи. акад. пед. наук України. (Ч.2, с. 137-143). Київ, Україна: Ін-т обдарованої дитини НАПН України.

6. Дубасенюк, О.А. (2010). Компетентнісний підхід у професійній підготовці вчителя. Формування естетичної компетентності особистості засобами народознавства. (С. 10-16). Житомир, Україна: Вид-во ЖДУ ім. І. Франка.

7. Сметанський, М. I. (2000). Методологічні засади активізації навчальнопізнавальної діяльності студентів. Шлях освіти, 4, 9-13.

\section{FOUNDATIONS OF QUESTION THEORY IN MODERN NATURAL EDUCATION}

Професіоналізм педагога: теоретичні й методичні аспекти. - Вип. 11. - Слов’янськ, 2019. 
В. НАДТОЧІЙ, В. МАСИЧ, Ю. ЛИМАРЕВА

Основи теорії запитань у сучасній природничій освіті

\author{
Viktor Nadtochii \\ Doctor of Physical and Mathematical Sciences, Professor of \\ the Department of Physics \\ SHEI "Donbass State Pedagogical University" \\ Sloviansk, Ukraine \\ ORCID ID 0000-0002-6289-0438 \\ nadtochiivn@gmail.com
}

\author{
Vitalii Masych \\ Doctor of Sciences in Pedagogics, Associate Professor of the Department \\ Physics and Cyber-Physical Systems \\ H. S. Skovoroda Kharkiv National Pedagogical University \\ Kharkiv, Ukraine \\ ORCID ID 0000-0002-8943-7756 \\ jugosloven9@yandex.ru \\ Yuliia Lymarieva \\ Candidate of Pedagogical Sciences, Associate Professor of \\ the Department of Physics \\ SHEI "Donbass State Pedagogical University" \\ Sloviansk, Ukraine \\ ORCID ID 0000-0002-5828-0231 \\ ulialymareva23@gmail.com
}

\begin{abstract}
Studying the issue of questions is extremely important for the organizers of the learning process. In addition to asking different levels of complexity and purpose, they now need to teach students questions to organize effective engagement. Therefore, this issue should be considered as the broadest and in various aspects.

Some aspects of this issue are reflected in the writings of modern scholars: questions as a method of self-assessment and self-control; educational problem as a basis for questions; dialogue training in professional and pedagogical activity; the role and place of questions in the creative activity of the individual.

The purpose of the article is to highlight the key points in personality training in formulating questions during the learning activity.

The active change of training methods from passive to active requires close interaction of all participants of the educational process, which is possible only if the construction of training based on questions and answers. Under these circumstances, a question plays a key role in supporting the continuous functioning of the learning system. The first task facing the teacher - to be interested. Further, the pedagogical process requires a strong capacity to sustain interest. This support is often provided through the use of a series of questions against the background of the teacher's monologic dialogue. This approach activates the mental activity of the individual. Sometimes, even at this stage, personal questions arise. Most often they appear by analogy. But at this stage it is a manifestation of the highest efficiency of the specified stage of formulation and use of questions in the educational process.

This method indicates the variability of possible approaches to awareness of the questions and, accordingly, the learning material. The material presented in the article gives grounds to believe that the prospects for further exploration should be to create methodological developments for
\end{abstract}

() ДВНЗ «Донбаський державний педагогічний університет» 
different sections of physics to organize the study of discipline based on questions and recommendations for their use in the educational process. education.

Key words: question; background; interest; awareness; logical connection; learning; self-

\section{REFERENCES}

1. Andreev, V. I. (2000). Pedagogy: a training course for creative self-development. Kazan, Russia: Tsentr innovatsionnykh tekhnologiy.

2. Walker, T. (2018). How to teach in Finland. Best School Education. N. Lavska (Tr.). Kyiv, Ukraine: Vydavnycha hrupa KM-B.

3. Volkova, N. P. (2006). Professional and pedagogical communication. Kyiv, Ukraine: Vydavnyctvo VC “Akademiya”.

4. Havrysh, I. V. (2006). Theoretical and methodological foundations of forming readiness of uture teachers for innovative professional activities. (Extended abstract of Doctoral dissertation). Luhansk, Ukraine.

5. Hurevych, R. S. (2014). Competency-based approach in vocational and pedagogical education. Kompetentnisnyi pidkhid v osviti: teoretychni zasady i praktyka realizatsiyi: Metodol. seminar Nats. akad. ped. nauk Ukrayiny. (Part 2, pp. 137-143). Kyiv, Ukraine: In-t obdarovanoyi dytyny NAPN Ukrayiny.

6. Dubaseniuk, O. A. (2010). Competency-based approach in teacher training. Formuvannya estetychnoyi kompetentnosti osobystosti zasobamy narodoznavstva (pp. 10-16). Zhytomyr, Ukraine: Vyd-vo ZHDU im. Franka

7. Smetanskyi, M. I. (2000). Methodological foundations of activization of students' learning and cognitive activity. Shliakh osvity, 4, 9-13.

Матеріали надійшли до редакції 16.11.2019 р. 